African Crop Science Journal by African Crop Science Society is licensed under a Creative Commons Attribution 3.0 Uganda License. Based on a work at www.ajol.info/ and www.bioline.org.br/cs DOI: http://dx.doi.org/10.4314/acsj.v24i1.5S

\title{
PREVALENCE OF BRUCELLOSIS IN LIVESTOCK AND INCIDENCES IN HUMANS IN EAST AFRICA
}

\author{
A.C. CHOTA, H.B. MAGWISHA, B. STELLA, E.K. BUNUMA, G.M. SHIRIMA', J.M. MUGAMBI ${ }^{2}$, \\ S.G. OMWENGA ${ }^{2}$, H.O. WESONGA ${ }^{2}$, P. MBATHA ${ }^{3}$ and S. GATHOGO ${ }^{3}$ \\ Tanzania Veterinary Laboratory Agency (TVLA), Veterinary Complex, 131 Nelson Mandela Road, \\ P. O. Box 9254, Dar es Salaam, Tanzania \\ ${ }^{1}$ Nelson Mandela Institution of Science and Technology (NM-AIST), P. O. Box 447, Tengeru, \\ Arusha, Tanzania \\ ${ }^{2}$ Veterinary Research Centre Muguga, Veterinary Sciences Research Institute, P. O. Box 32-00902, \\ Kikuyu, Kenya \\ ${ }^{3}$ Central Veterinary Laboratories Private Bag 00625 Kangemi, Kenya \\ Corresponding author: chotaandrew@gmail.com
}

\begin{abstract}
Brucellosis is an emerging zoonotic disease that poses a threat to both livestock and public health in east Africa. There are several reports of occurrence of the disease in livestock populations especially in Tanzania and Kenya, suggesting chances of increased spread to humans, and the disease being misdiagnosed for malaria. The objective of this study was to determine brucellosis prevalence in livestock and incidence in humans among pastoralists and agro-pastoralists communities in some areas of Kenya and Tanzania. A total of 2349 ruminants were screened using different serological techniques, in the selected areas. Serum samples from the Southern Highlands Zone (SHZ), Northern zone (NZ) and Eastern Zone (EZ) were screened using Rose Bengal Plate Test (RBPT) antigen, and later positive samples were confirmed using competitive enzyme linked immune-sorbent assay (c-ELISA). Results showed prevalence of $11.4 \%$ in the SHZ ( $n=799), 2.4 \%$ in the EZ ( $n=169)$ and $1 \%$ in the NZ ( $=408)$. Milk ring test was used to test milk samples from Migori, West Pokot and Mwingi, and the prevalences recorded in cattle were 17.9\% ( $\mathrm{n}=56)$ in 2012 and $11.7(\mathrm{n}=77)$ in 2014. Within the same period, West Pokot recorded prevalence of up to $21.9 \%(n=96)$ in cattle and $16.7 \%(n=6)$ in goats. Generally, Migori had lower prevalence in Kenya, but being the third lower in Tanzania and Kenya with the prevalence being $4.3 \%(n=70)$ in goats and 2.2\% $(\mathrm{n}=45)$ in goats. Serum from cattle and goats were tested using compliment fixation test (CFT); showing $0.9 \%$ $(n=212)$ prevalence in Migori. In West Pokot, the prevalence was 4.0\% $(n=101)$ in cattle, 20\% $(n=100)$ in goats and $13.8 \%(=29)$ in sheep; whereas in Mwingi prevalence was 4.75\% $(n=43)$ and 9.5\% $(n=21)$ in cattle and goats respectively. A total of 1,140 human cases were followed up in selected study areas where livestock samples were collected, and an overall incidence of $22.7 \%(\mathrm{n}=1140)$ was confirmed. Selected areas in Tanzania had an incidence of $28.2 \%(n=578)$ and in Kenya $17.1 \%(n=562)$. Brucellosis is endemic in many areas of Tanzania and Kenya and pose a high risk to human health.
\end{abstract}

Key Words: Agro-pastoral, pastoral, public health

\section{RÉSUMÉ}

La brucellose est une zoonose qui constitue une menace pour la sante animale et humaine dans 1'Afrique de 1'Est. Il existe beaucoup de rapports signalant la présence de cette maladie dans les populations d'animaux, specialement en élevage dans la Tanzanie et au Kenya. Ces rapports font aussi état de ce qu'il y ait des chances de contamination humaine, et la maladie est en train d'être mal diagnostiquée parce qu'elle est confondue au paludisme. L'objectif 
de cette étude était de déterminer la prévalence de brucellose en élevage et son incidence dans les humains, dans les communautés de pastoralistes et agro-pastoralistes en Tanzanie et au Kenya. Un ensemble de 1,702 ruminant ont été dépistés dans les zones d'étude en se servant de techniques sérologiques différentes. Des échantillons de sérum venant de la zone Sud (SHZ), de la zone Nord (NZ) et de la zone Est (EZ) ont été analyses par des tests de détection d'antigène au Rose Bengale sur plaque (RBPT), et plus tard, les échantillons positifs ont été confirmes par des épreuves immuno-enzymatiques (c-ELISA). Les resultats montrait une prévalence de 11,4\% dans la SHZ ( $n=799) ; 2,4 \%$ dans l'EZ $(n=169)$ et $1 \%$ dans la NZ $(n=408)$. Des épreuves de l'anneau sur le lait ont permis de tester les échantillons de lait de Migori, West Pokot et Mwingi, et de prévalence enregistrée chez le bovin étaient de 17,9\% (n=56) en 2012 et 11,7 $(n=77)$ en 2014. Dans la même période, West Pokot a enregistré un taux de prévalence de $21.9 \%$ ( $n=96$ ) chez le bovin et $16,7 \%$ ( $n=6)$ chez les caprins. De façon générale, Migori exhibait de faibles taux de prévalence au Kenya, mais s'est classe troisième faible taux en Tanzanie et au Kenya avec une prévalence de 4,3\% (n=70) chez les caprins 2,2\% (n=45) chez les caprins. Du sérum prélevé chez les bovins et caprins ont été testes grâce au test de fixation de compléments (CFT); montrait $0.9 \%(\mathrm{n}=212)$ de prévalence en Migori. A West Pokot, la prévalence était de 4,0\% ( $\mathrm{n}=101)$ chez les bovins, $20 \%(\mathrm{n}=100)$ chez les caprins et 13,8\% (=29) chez les ovins; tandis qu'en Mwingi la prévalence était de 4,75\% (n=43) et 9,5\% ( $n=21)$ respectivement chez les bovins et caprins. Un ensemble de 1,140 cas humains ont été suivis dans la zone d'étude ou les animaux ont été échantillonnés. Une incidence globale de $22,7 \%(\mathrm{n}=1140)$ a été confirmée. Les zones sélectionnées en Tanzanie avaient une incidence de 28,2\% (n=578) et 17,1\% ( $\mathrm{n}=562)$ au Kenya. Cet étude a montré que la brucellose continue d'être endémique dans plusieurs zones de la Tanzanie et du Kenya, et ceci constitue un grand risqué pour la santé humaine.

Mots Clés: Agro-pastoral, pastoral, sante publique

\section{INTRODUCTION}

Brucellosis is among the most widely distributed zoonoses of economic importance in developing countries. Most of the zoonotic diseases are poorly controlled, and endanger economically disadvantageous communities (Perry et al., 2001; WHO, 2006). In livestock, brucellosis results in reduced productivity, abortions and weak offsprings; thus, it is a major setback to both national and international livestock trade. Estimates of losses in meat and milk production, as a result of the disease, were US\$800 million annually in the USA (Richey and Harrell, 2008). Despite the productivity losses incurred globally, the disease prevalence and incidences in humans are not well documented, particularly in Africa.

Milk consumption is a source of protein supply in many families in Africa. However, consumption of raw milk and its products can result in transmission of diseases that are zoonotic, such as Brucellosis (Ramos et al., 2008; VVMA, 2009). Despite farmers knowledge of the possibility of disease spread through consumption of raw milk, they participate in high risk behaviours that predispose them to the diseases (Holt et al., 2011).
The spread of the disease is increasing due to the fact that animals hosting the pathogens do not show clinical symptoms, yet in developing countries, milk distributions chains encourage supply of unprocessed milk (Kurwijila and Henriksen, 1994; Wareth et al., 2014) and, hence spread of diseases (Racloz et al., 2013).

Although many Brucella species can cause disease in human, Brucella arbotus and Brucella melitensis are the most implicated species (Franco et al., 2007). Brucella melitensis is the most common and more virulent species, causing human disease (Pappas et al., 2005).

Brucellosis in humans is characterised by intermittent fever, accompanied by generalised pain (WHO, 2006). The disease manifests itself in humans as an acute case that may persist and progress to a chronic and debilitating form, resulting into many complications (Corbel et al., 2006; Roop et al., 2009). However, clinical signs are not specific and the disease can be confused with typhoid fever, malaria, rheumatic fever and relapsing fever. It is debilitating and requires prolonged treatment, with a combination of antibiotics (Kunda et al., 2010).

This paper presents information on the seroprevalence of brucellosis in milk and serum 
samples of bovines, caprine, ovines and camels; and incidence of human cases in selected areas of Tanzania and Kenya.

\section{MATERIALS AND METHODS}

Study area. The study was conducted in pastoral and agropastoral communities of Tanzania and Kenya, during 2012 to 2014. Samples were collected from Southern Highland Zones (SHZ), Eastern Zone (EZ) and Northern Zone (NZ) in Tanzania; and from counties of West Pokot, Mwingi and Migori in Kenya.

In Tanzania where a typical tropical climate (ICID, 2010) was experienced, SHZ receives mean rainfall of $1250 \mathrm{~mm}$ per annum (Mbululo and Nyihirini, 2012). Migori located in the southern western Kenya experiences similar climatic condition to Northern parts of Tanzania, which is semi-arid, receiving $600 \mathrm{~mm}$ rainfall per annum. The EZ has an average of $1000 \mathrm{~mm}$ rainfall per annum (Kabede et al., 2010; Geutjes and Knutsson, 2014); while West Pokot county records 700 to $1600 \mathrm{~mm}$ per annum (Geutjes and Knutsson, 2014). Major economic activities in these communities is agriculture (including livestock keeping) which contributes $56 \%$ of the GDP, employs $80 \%$ of the work force; and provides $60 \%$ of the total earnings (NAPA, 2006).

Study design. Epidemiological studies were employed and an observational cross sectional study design was used in livestock populations in Tanzania and Kenya. In order to reduce potential variations in the study results, final data included in this study were restricted to seroepidemiologic field surveys on traditionally managed animals with a known number of sampled and positively tested animals during 2012 and 2014 (Mangen et al., 2002).

Sample collection. Sample size was calculated using the standard formula for estimation of proportions (Martin et al., 1987), and the population was considered to be a large number. In livestock, 2349 samples were collected the population was considered infinite and the prevalence of $21 \%$ from previous studies was used in the calculation at $95 \%$ confidence level. On the other hand, in humans 1,140 samples were collected at the prevalence of $18 \%$ from previous studies was used in the calculation at $95 \%$ confidence level, in both livestock and humans the absolute error of precision of $5 \%$ was used. Blood samples from animals were collected from jugular veins in plain vacutainer tubes, and stored in iced cool boxes, decanted after 90 minutes and serum preserved in cryotubes, labeled and kept at $4{ }^{\circ} \mathrm{C}$ in Tanzania and $-20^{\circ} \mathrm{C}$ in Kenya (WHO. 2005), storage conditions selected depending on the expected duration of storage.

Laboratory analysis. A total of 1376 serum samples from animals were screened using Rose Bengal Plate Test (RBPT) as described by Dý'az et al. (2011). Positive samples were labeled and confirmed using the competitive Enzyme Linked Immunosorbent Assay (c-ELISA) test (Perret et al., 2001) in Tanzania, and 509 samples by Compliment fixation Test in Kenya (OIE, 2012). The procedure were opted depending on easy access to test reagents. Other 464 samples in Kenya were tested in the field using a Milk Ring Test (MRT). Because the test detects false positive (Low sensitivity) due to positive reactions from samples taken shortly after parturition, near the end of lactation period or from mastitic quartered (MacMillan, 1990), animals in these conditions were avoided during sampling. In humans, a follow up was carried out in health centres in Korogwe-Tanzania and OrtumKenya. Based on c-ELISA, CFT and MRT results, farmers were advised to dispose of positive reactors. The advice targeted to control further spread of the disease among animals and human beings.

Data analysis. The data were recorded and organised using Microsoft Excel 2007. Statistical analysis was carried out using Epi Info 7 statistical software. MedCalc ${ }^{\circledR}$ statistical software was used to compare proportions of the variables. Statistical significance between variables was examined using the Students T-test for comparison of means and p-value at critical probability of $\mathrm{P}<0.05$. 
TABLE 1. Catlle c-ELISA results and RBPT screening in different ecological zones in Tanzania

\begin{tabular}{lrrr}
\hline Ecological zones & $\begin{array}{c}\text { Confirmed } \\
\text { brucellosisc-ELISA }\end{array}$ & $\begin{array}{c}\text { Positive for brucellosis } \\
\text { RBPT screening }\end{array}$ & $\begin{array}{r}\text { Percentage of } \\
\text { c-ELISA / RBPT }\end{array}$ \\
\hline SHZ & $11.4 \%(n=799)$ & $12.6 \%(n=799)$ & $90.1 \%(N=101)$ \\
NZ & $1 \%(n=408)$ & $1.7 \%(n=408)$ & $57.1 \%(N=7)$ \\
EZ & $2.4 \%(n=169)$ & $2.4 \%(n=169)$ & $100 \%(N=4)$ \\
\hline
\end{tabular}

$n=$ Number of animals at Risk in respective zones. $N=$ Number of animals tested positive to RBPT, $S H Z=101, N Z=7, E Z=$ 4

\section{RESULTS}

In Tanzania, Brucellosis prevalence was confirmed by c-ELISA. Prevalence was highest in the SHZ (11.4\%), followed by EZ $(2.4 \%)$ and least in the NZ (1\%). From the RBPT, screening values were $12.6 \%$ in SHZ, $2.4 \%$ in EZ with $100 \%$ percentage between the test and $1.7 \%$ in NZ (Table 1).

In Kenya, antibodies to Brucella species were detected in bovines, caprines and ovines. In Migori, results from MRT in bovine declined from $17.86 \%(n=56)$ in 2012 to $11.69 \%(n=77)$ in 2014. One caprine was screened in 2012 and was negative, whereas the other two species ovine and camels were not screened due to lack of farmers' cooperation. Results in West Pokot indicated a decline in disease prevalence in bovines, recording $21.88 \%(\mathrm{n}=96)$ in 2012 and $21.15 \%(n=52)$ in 2014. However, an increase in brucellosis prevalence was recorded in caprine, where prevalence increased from $4.65 \%(n=43)$ in 2012 to $16.67 \%$ ( $n=6)$ in 2014. In 2012, there were no positive cases in both ovines $(n=13)$ and camels $(n=5)$, and no screening was done in both species in 2014 as some farmers were not willing to allow sampling the animals and the low number of animals kept. Only bovines and caprine were screened in 2012 in Mwingi, with results showing prevalence of $2.22 \%(n=45)$ and $4.29 \%(n=70)$. Generally, MRT results indicated higher prevalences in West Pokot in bovines $21.88 \%$ $(\mathrm{n}=56)$; and lower prevalence in Mwingi in bovines $2.22 \%(n=45)$. No cases were recorded in caprine $(n=1)$, ovine $(n=13)$ and camels $(n=5)$ (Table 3).

The other samples were tested using Compliment Fixation Test (CFT) and prevalences were higher in caprine $20 \%(\mathrm{n}=100)$ and ovine
$13.79 \%(n=29)$ in West Pokot, compared with bovine that recorded the lowest prevalence of $0.94 \%(n=212)$ in Migori. Similar to MRT, higher values were recorded in West Pokot than in Migori and Mwingi (Table 3). However, generally MRT recorded higher prevalences than CFT in bovines; while it was the reverse for caprine and ovines (Tables 2 and 3)

Prevalence of human brucellosis (Table 4) was recorded in both Tanzania and Kenya. Results showed that the incidence was higher in Tanzania (28.2\%, $\mathrm{n}=578)$, compared to Kenya $(17.1 \%$, $\mathrm{n}=562$ ). Suspected cases were recorded from January to July, 2014 in Tanzania and from June, 2013 to April, 2014 in Kenya.

\section{DISCUSSION}

It is clear from this study that the disease still poses a big threat to human health and livestock wealth in east Africa. In Tanzania, the disease spreading pattern seems to be from North to South of Tanzania, following trends of animal movement towards the South (Mwambene et al., 2014), which results in animals meeting frequently in different water sources.Pastoral and agropastoral farming systems are still being practiced, despite the efforts to modernise livestock farming through agro-pastoralism (Msalale, 2007). Studies by Muendo et al. (2012) resulted in isolation of Brucella melitensis biovar 1, and Brucella abortus biovar 3 from milk and aborted fetus materials, respectively in central Kenya. In another study, Waghela et al. (1978) reported 11 reactors in RBPT, 11 in SAT and 21 in CFT out of 172 samples from camels. In the current study, camels showed negative results, possibly due to few samples collected as most farmers were unwilling to let their animals be sampled. 


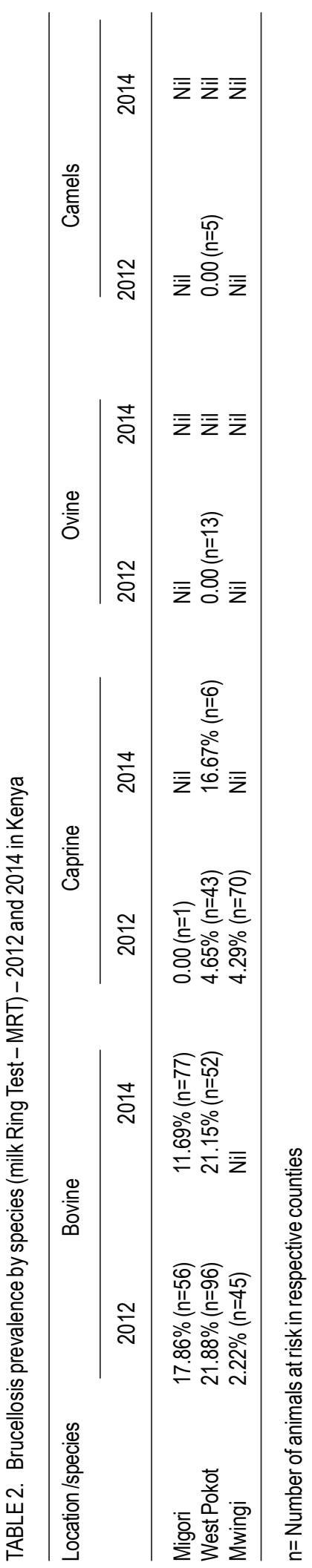

Brucellosis prevalence in this study ranged from $1 \%$ in NZ of Tanzania from c-ELISA results, to $21.88 \%$ in West Pokot in MRT. Generally, there is a clear indication that all screening techniques picked up positive reactors. These results are in line with those of Kangethe et al. (2000), who reported prevalences of 4.9 and $3.9 \%$ by ELISA and 2.4 and $3.4 \%$ by MRT at milk consumer-levels and informal market levels, respectively. In all these studies, the positives were picked in milk or in sera collected from bovines, ovines and caprine, with no evident clinical signs. These findings concur with those of Shirima et al. (2014). Similarly, the prevalence from this study in NZ, SHZ, Mwingi, West Pokot and Migori are in a similar range with those reported by Waghela and Karstad (1986). Free range production systems practiced in most parts of these countries, also helps to maintain the disease in both animal and human populations. Cultural practices of some communities that encourage consumption of raw livestock products, e.g. whole blood and raw milk, favour the spread of the disease. Obtaining milk from the market $(\mathrm{P}<0.00001$, odds ratio 7.3, 95\% confidence interval 2.5-21.1) and drinking unboiled milk ( $\mathrm{P}<0.0001$, odds ratio $8.5,95 \%$ confidence interval, 4.2-17.3) were significantly associated with brucellosis spread (Kiambi, 2011).

Human brucellosis has been evident in this study, with Tanzania having more incidences than Kenya. In both countries, screening of the disease should be considered in patients who have not responded to treatments for malaria. This was reflected in the much longer duration of illness of brucellosis compared to malaria. Clearly, early diagnosis of brucellosis is required (Muriuki, 1994; Kunda et al., 2007). Muriuki et al.'s (1997) study in Narok, classified $0.8 \%(n=1,037,875)$ of all 'flu-like' syndromes in humans as brucellosis, and $21.2 \%$ of these tested positive for Brucellosis on RBT. The results from this study are relatively higher than the ranges of 3 to $8 \%$ recorded in Sub-Saharan Africa (Baba et al., 2001). However, there is still need for more sosphicated techniques such as molecular techniques in places where the disease prevalence is thought to be much higher. Kiambi (2011) detected sero-prevalence of brucellosis using Febrile Rapid Diagnostic Kit was $31.8 \%$; while the true prevalence detected by PCR method was $15.4 \%$. 
TABLE 3. Brucellosis prevalence by species CFT - 2014 in selected counties in Kenya

\begin{tabular}{lrrr}
\hline Location/species & \multicolumn{1}{c}{ Bovine } & \multicolumn{1}{c}{ Caprine } & \multicolumn{1}{c}{ Ovine } \\
\hline Migori & $0.94 \%(n=212)$ & $0.00(n=2)$ & $0.00(n=1)$ \\
West Pokot & $3.96 \%(n=101)$ & $20 \%(n=100)$ & $13.79 \%(n=29)$ \\
Mwingi & $4.65 \%(n=43)$ & $9.52 \%(n=21)$ & Nil \\
\hline
\end{tabular}

$\mathrm{n}=$ Number of animals at risk in respective counties

TABLE 4. Brucellosis prevalence in human beings in Ortum - Kenya and Korogwe - Tanzania

\begin{tabular}{lll}
\hline Location & Time interval & Brucellosis prevalence $(\%)$ \\
\hline Tanzania (Korogwe) & January 2014 to July 2014 & $28.2(n=578)$ \\
Kenya (Ortum) & May 2013 to April 2014 & $17.1(n=562)$ \\
\hline
\end{tabular}

$n=$ Number of people screened in the specified time and locations

\section{CONCLUSION}

Brucellosis is still an endemic disease in Tanzania and Kenya, and affects both livestock and humans.

\section{ACKNOWLEDGEMENT}

Thanks to the Chief Executive Officer (CEO) of Tanzania Veterinary Laboratory Agency (TVLA), the health facilities in Kenya and Tanzania for the granted sample storage and analysis. Authors appreciate the Eastern Africa Agricultural Productivity Project (EAAPP) for funding this work. The Association for Strengthening Agricultural Research in Eastern and Central Africa facilitated the publication of this paper.

\section{REFERENCES}

Baba, M.M., Sarkindared, S.E. and Brisibe, F. 2001. Serological evidence of brucellosis among predisposed patients with pyrexia of unknown origin in the eastern Nigeria. Central European Journal of Public Health 9: $158-161$.

Corbel, M.J., Alton, G.G., Ariza, J. and Banai, M. 2006. Brucellosis in Humans and Animals. World Health Organization. Geneva, Switzerland.
Dý'az, R., Casanova, A., Ariza, J. and Moriyo'n, I. 2011.The Rose Bengal Test in human Brucellosis: A neglected test for the diagnosis of a neglected disease. PLoS Neglected Tropical Disease 5(4): e950. doi:10.1371/ journal.pntd.0000950.

Franco, M.P., Mulder, M., Gilman, R.H. and Smits, H.L. 2007. Human brucellosis. Lancet Infectious Diseases 7: 775 -786.

Geutjes, L. and Knutsson, P. 2014. Coping with climate variability in West Pokot, Kenya. Master thesis in Global Studies, University of Gothenburg. pp.7-9.

Holt, H. R., Eltholth, M. M., Hegazy, Y. M., ElTras, W. F, Tayel, A. A. and Guitian, J. 2011. Brucella spp. infection in large ruminants in an endemic area of Egypt: Cross-sectional study investigating seroprevalence, risk factors and livestock owner's knowledge, attitudes and practices (KAPs). BMC Public Health 11:341

ICID. 2010. Tanzania country Profile. http:// www.icid.org. visited on 18.02.2015.

Kangethe, E.K., Arimi, S.M., Omore, A.O., McDermott, J.J., Nduhiu, J.G., Macharia J.K. and Githua, A. 2000. The prevalence of antibodies to brucella abortus in marketed milk in Kenya and its public health implications. $3^{\text {rd }}$ All Africa Conference on Animal Agriculture. 6 - 9. 
Kebede, A.S., Brown, S. and Nicholls, R.J. 2010. Synthesis Report: The Implications of Climate Change and Sea-Level Rise in Tanzania -The Coastal Zones: Report submitted to: Global Climate Adaptation Partnership (GCAP) pp. $1-32$.

Kiambi, S.G. 2011. Prevalence and factors associated with brucellosis among febrile patients attending Ijara District Hospital, Kenya MSc. Thesis, Jomo Kenyatta University of Agriculture and Technology. Nairobi, Kenya.

Kunda, J., Fitzpatrick, J., French, N., Kazwala, R., Kambarage, D., Mfinanga, G.S., MacMillan, and Cleveland, S. 2010. Quantifying risk factors for human brucellosis for rural northern Tanzania. PloS One 5(4). www.plosone.org.

Kunda, J., Fitzpatrick, J., Kazwala, R., French, N.P., Shirima, G., Kambarage, D., Bronsvoort, $M$ and Cleaveland, S. 2007. Health-seeking behavior of human brucellosis cases in rural Tanzania. BMC Public Health 7:315

Kurwijila, L. R. and Henriksen, J. 1994. Milk supply to urban centres in Tanzania with particular reference to the city of Dar Es Salaam. Workshop on the "Market Orientation of Small scale Milk Producers and their Organisations" held at Morogoro, Tanzania, 20 - 24 $4^{\text {th }}$ March, 1994.

Lupindu, A.M., Oosting, S.J. and Eilers, C.H.A.M. 2007.Pastoralists in Mbeya District of Tanzania and their perception of the national livestock policy. MSc thesis, University of Wageningen, The Netherlands.

MacMillan, A. 1990. Conventional serological tests. Animal Brucellosis 206:153-197.

Mangen, M.J., Otte, J., Pfeiffer, D., Chilonda, P. 2002. Bovine brucellosis in Sub-Saharan Africa: Estimation of sero-prevalence and impact on meat and milk offtake potential. Food and Agriculture Organization. Livestock Information and Policy Branch, AGAL. pp. 916

Martin, S.W., Meek, H.A and Willeberg, P.1987. Veterinary epidemiology: Principles and Methods. Iowa State University Press, Ames, Iowa. pp. 45.

Mbululo, Y. and Nyihirani, F. 2012. Climate characteristics over Southern Highlands
Tanzania. Atmospheric and Climate Sciences 2:454- 463 .

McDermott, J., Grace, D. and Zinstag, J. 2013. Economics of Brucellosis impact and control in low-income countries', Revue scientifique et technique, Office International des Epizooties 32 (1): 249 - 261.

Msalale, L.A., Oosting, S.J. and Eilers, C.H.A.M. 2007. Pastoralists in Mbeya District of Tanzania and their perception of the national livestock policy MSc thesis. Submitted at University of Wageningen, The Netherlands.

Muendo, E.N., Mbatha, P.M., Macharia, J.M., Abdoel, T.H., Janszen, P.V., Pastoor, R. and Smits, H.L.2012. Infection of cattle in Kenya with Brucella abortus biovar 3 and Brucella melitensis biovar 1 genotypes. Troprical Animal Health Production 44:17-20.

Muriuki S.M., McDermott J.J., Arimi S.M., Mugambi, J.T. and Wamola, I. A. 1997. Criteria for better detection of brucellosis in the Narok District of Kenya. East Africa Medical Journal 74(5):317-20.

Muriuki, S.M.K., Arimi, S.M. and McDermott, J.J. 1994.Brucellosis as a cause of human illness in Narok district, Kenya. The Kenya Veterinarian 18(2):537-539.

Mwambene, P.L., Mbwile, R.P., Hoeggel, F.U., Kimbi, E.C., Materu, J., Mwaiganju, A. and Madoffe, S. 2014. Assessing dynamics of forced livestock movements, livelihoods and future development options for pastoralists/ agro-pastoralists in Ruvuma and Lindi Regions, in the Southern Tanzania. Livestock Research for Rural Development 26 (1).

NAPA, 2006. National Adaptation Programme of Action (NAPA) for Tanzania. United Republic of Tanzania, Division of Environment, April, 2006, Maputo, Mozambique.

OIE. 2012. Bovine Brucellosis: Terrestrial Manual. pp. 616-650.

Pappas, G., Akritidis, N., Bosilkovski, M. and Tsianos, E. 2005. Brucellosis. New England Journal of Medicine 352: 2325 - 2336.

Perret, L., Brew, S., Tucker, J. and Macmillan, A.P. 2001. A Guide to the EIA techniques used in the diagnosis of brucellosis at the VLA Weybridge. Veterinary Laboratory Agencies, New Haw, Addlestone Surrey, United Kingdom. 
Perry, B.D., McDemott, J.J. and Randolf, T.F. 2001 Can epidemiology and economics make a meaningful contribution to national livestock disease control? Preventive Veterinary Medicine and Hygiene (89): 228 - 230.

Racloz, V., Schelling, E., Chitnis, N., Roth, F. and Zinsstag, J. 2013. Persistence of brucellosis in pastoral systems Revue scientifique et technique, Office International des Epizooties 32 (1):61-70.

Ramos, M., Bernal, E., Esguevillas, T., LopezGarcia, P., Gaztambide, M. S. and Gutierrez, F. 2008. Non-imported brucellosis outbreak from unpasteurized raw milk in Moroccan immigrants in Spain. Epidemiology and Infections 136:1552-1555.

Richey, E. J. and Harrell, C. D. 2008. Herd Management; IFAS Extension. University of Florida, USA. pp. 74.

Roop, R.M., Gaines, JM., Anderson, E.S., Caswell, C.C. and Martin, D.W. 2009. Survival of the fittest: how Brucella strains adapt to their intracellular niche in the host. Medical Microbiology and Immunology (Berl) 198: $221-238$.

Shirima, G.M., Masola, S.N., Malangu, O.N. and Schumaker, B.A. 2014. Outbreak investigation and control case report of brucellosis: Experience from livestock research centre, Mpwapwa, Tanzania, Onderstepoort Journal of Veterinary Research 81(1); Article number 818, 4 pages. http://dx.doi.org/10.4102/ ojvr.v81i1,818.
Smits, H.L. and Cutler, S.J. 2004. Contribution of biotechnology to control and prevention of brucellosis in Africa. African Journal of Biotechnology 12 (3):631 - 636.

Vermont Veterinary Medical Association (VVMA). 2009. Raw milk sales and consumption/ 88 Beech Street, Essex Junction, VT 05452 (802) 878-6888 voice • (802) 878-2871 fax, www.vtvets.org•kathy@ vtvets.org visited on 13.02.2015

Waghela, S. and Karstad, L. 1986. Antibodies to brucella spp. Among blue wildebeest and African buffalo in Kenya. Journal of Wildlife Diseases 22(2):189-192.

Waghela, S., Fazil, M.A., Gathuma, J.M. and Kagunya, D.K. 1978. A serological survey of brucellosis in camels in north-eastern province of Kenya Tropical Animal Health and Production 10:28-29.

Wareth, G., Melzer, F., Elschner, M. C., Neubauer, H. and Roesler, U. 2014. Detection of Brucella melitensis in bovine milk and milk products from apparently healthy animals in Egypt by real-time PCR. Journal of Infection in Developing Countries 8(10):1339-1343.

WHO. 2005. Manual on the management, maintenance and use of blood cold chain equipment: Marketing and dissemination, World Health Organization, 20 Avenue Appia, 1211 Geneva 27, Switzerland. pp. 5-12.

WHO. 2006. July, Fact sheet. N173: The control of neglected zoonotic diseases: A route to poverty alleviation. Www.absa.org/pdf/ ZoonoticFactSheet.pdf 